\title{
Conductivity studies of grafted natural rubber and ionic liquid electrolyte systems
}

\author{
M.F. Rahmat ${ }^{a}$, Y. Alias ${ }^{\mathrm{a} *}$, W.J. Basirun ${ }^{\mathrm{a}}$, L. Aldous ${ }^{\mathrm{b}}$ and C. Hardacre ${ }^{\mathrm{b}}$ \\ ${ }^{a}$ Department of Chemistry, Faculty of Science, University of Malaya, 50603 Kuala Lumpur. \\ ${ }^{\mathrm{b}}$ School of Chemistry and Chemical Engineering, Queen's University, Belfast, BT9 5AG, N. Ireland, UK. \\ * yatimah70@um.edu.my (Corresponding author) \\ Received in $15^{\text {th }}$ May 2009, accepted in revised form $20^{\text {th }}$ July 2009.
}

ABSTRACT Ionic liquids containing the 1-butyl-1-methylpyrrolidinium $\left(\left[\mathrm{C}_{4} \mathrm{mPyrr}\right]^{+}\right)$cation and bis(trifluoromethanesulfonyl)imide $\left(\left[\mathrm{NTf}_{2}\right]^{-}\right)$anion have been synthesized and incorporated in $49 \%$ PMMA grafted natural rubber together with lithium salts to obtain solid polymer electrolytes (SPEs). The resultant SPEs obtained, are freestanding, flexible film and translucent and show conductivity over a wide range of $10^{-}$ ${ }^{3}-10^{-5} \mathrm{~S} \mathrm{~cm}^{-1}$. Polymer electrolytes containing $80 \%$ of $\left(\mathrm{MG} 49: \mathrm{LiCF}_{3} \mathrm{SO}_{3}\right)$ and $20 \%$ of $\left[\mathrm{C}_{4} \mathrm{mPyrr}\right]\left[\mathrm{NTf}_{2}\right]$ showed the highest conductivity of $2.11 \times 10^{-3} \mathrm{~S} \mathrm{~cm}^{-1}$ at room temperature. The examination of the ionpolymer interactions and ionic conductivity are discussed and investigated by FT-IR and Electrochemical Impedance Spectroscopy (EIS) respectively.

\begin{abstract}
ABSTRAK Cecair ionik yang mengandungi kation 1-butil-1-metilpirrolidinium $\left(\left[\mathrm{C}_{4} \mathrm{mPyrr}\right]^{+}\right)$dan anion bis(trifluoromethanasulfonil)imida $\left(\left[\mathrm{NTf}_{2}\right]^{-}\right)$telah disintesiskan dan digabungkan bersama garam litium dengan 49\% PMMA (MG49) dicantumkan getah asli, untuk menghasilkan elektrolit polimer pepejal (EPP). EPP yang terhasil, adalah bebas, filem yang fleksibel, lut cahaya dan menunjukkan nilai konduktiviti dalam lingkungan $10^{-3}-10^{-5} \mathrm{~S} \mathrm{~cm}^{-1}$. Elektrolit polimer yang mengandungi $80 \%\left(\mathrm{MG} 49: \mathrm{LiCF}_{3} \mathrm{SO}_{3}\right)$ dan $20 \%$ $\left[\mathrm{C}_{4} \mathrm{mPyrr}\right]\left[\mathrm{NTf}_{2}\right]$ menghasilkan konduktiviti tertinggi pada suhu bilik iaitu $2.11 \times 10^{-3} \mathrm{~S} \mathrm{~cm}^{-1}$. Kajian mengenai interaksi antara ion-polimer dengan konduktiviti ionik masing-masing dijalankan dengan FT-IR dan Spektroskopi Impedans Elektrokimia.
\end{abstract}

(Keywords: room temperature ionic liquid/solid polymer electrolyte/PMMA grafted natural rubber)

\section{INTRODUCTION:}

Room temperature ionic liquids (RTILs) have attracted considerable attention due to their exceptional properties in terms of high ionic conductivity, wide electrochemical windows, low volatility and low flammability [1,2]. With such features, RTILs have been largely investigated as electrolytes for electrochemical applications such as the electrodeposition of electropositive metals [3,4], light emitting electrochemical cells [5], photoelectrochemical cells [6], electrochemical capacitors [7], fuel cells [8] and batteries [9]. To date, the majority of RTIL which have been employed contain organic cations, such as quarternary ammonium [10], pyridinium [11], pyrrolidinium [12], pyrazolium [13], piperidinium
[14] and particularly imidazolium [15], combined with a variety of anions, including hexafluorophosphate $\quad\left(\left[\mathrm{PF}_{6}\right]^{-}\right)$, bis(trifluoromethanesulfonyl)imide

$\left(\left[\mathrm{N}\left(\mathrm{CF}_{3} \mathrm{SO}_{3}\right)_{2}\right]^{-}\right.$or $\left.\left[\mathrm{NTf}_{2}\right]^{-}\right) \quad[10]$, trifluoromethanesulfonate or triflate $\left(\left[\mathrm{CF}_{3} \mathrm{SO}_{3}\right]^{-}\right)$ [16], and tris(trifluoromethanesulfonyl)methide $\left(\left[\left(\mathrm{CF}_{3} \mathrm{SO}_{2}\right)_{3} \mathrm{C}\right]^{-}\right)$. Amongst these, the $\left[\mathrm{N}\left(\mathrm{CF}_{3} \mathrm{SO}_{3}\right)_{2}\right]^{-}$anion has been found to be particularly effective in producing RTILs having low viscosity, high conductivity and high electrochemical stability $[14,15]$. These properties have been used to enhance the conductivity of poly(ethyleneoxide) (PEO)-LiNTf 2 based solid polymer electrolytes (SPEs). The addition of a series of $N, N$-alkyl,methylpyrrolidinium bis (trifluoromethanesulfonyl)imide RTILs was found 
to increase the ionic conductivity these SPEs above $10^{-4} \mathrm{~S} \mathrm{~cm}^{-1}$ at room temperature without any decrease of the electrochemical stability window of the polymer electrolyte $[2,12]$.

Although the ionic conductivity is improved in general by adding of RTILs into polymer matrix, the choice of ion-conductive polymers is of importance. Among the polymers that found to be useful to form such electrolytes include polyacrylonitrile (PAN) [19], poly(vinyl chloride) (PVC) [20], polyanaline (PAn) [21] and polythiophenes (PT) [22]. However, some of the polymers showed relatively poor ambient conductivity (about $10^{-8} \mathrm{~S} \mathrm{~cm}^{-1}$ ) due to their high crystallinity, e.g. PEO, widely studied as the classical polymer matrix for SPEs [23,24]. Therefore, significant effort has been undertaken in order to modify the polymer matrix in order to generate an amorphous system which has improved interfacial stability with electrode. In present study, the introduction of RTILs incorporated with $\mathrm{LiCF}_{3} \mathrm{SO}_{3}$ and $\mathrm{MG} 49$ films were investigated using electrochemical impedance spectroscopy (EIS) and FT-IR.

\section{METHOD AND METHODOLOGY}

49\% PMMA grafted with natural rubber was commercially available as MG 49 (Green HPSP Co. Ltd.). Lithium trifluoromethanesulfonate $\left(\mathrm{LiCF}_{3} \mathrm{SO}_{3}\right)$ (Sigma-Aldrich), dichloromethane (DCM) and tetrahydrofuran (THF) (Fischer Scientific) were used as received. 1-Butyl-1methylpyrrolidinium

bis(trifluoromethanesulfonyl)imide

$\left[\mathrm{C}_{4} \mathrm{mPyrr}\right]\left[\mathrm{NTf}_{2}\right]$ ionic liquid was synthesized using previous method [1].

\section{Thin Film Preparation}

MG 49 was dried under vacuum for 3 days at 50 ${ }^{\circ} \mathrm{C}$ before use and was cut into grain size. The dried and granulated material was dissolved in DCM using homogenizer and thereafter a solution of $\mathrm{LiCF}_{3} \mathrm{SO}_{3}$ in THF was mixed with MG 49 solution at the required ratio followed by addition of $\left[\mathrm{C}_{4} \mathrm{mPyrr}\right]\left[\mathrm{NTf}_{2}\right]$ under continuous stirring. The resulting viscous solution was cast on a glass petri dish, and solvents were allowed to evaporate is shifted to $1732 \mathrm{~cm}^{-1}$ was observed. This shifting may be due to interaction of methyl methacrylate group from PMMA which grafting in slowly at room temperature. The films were prepared by drying in vacuum oven for few days and stored in a dessicator before use.

\section{Conductivity Measurements}

The ionic conductivity of the polymer electrolytes was determined by means of electrochemical impedance spectroscopy (EIS) with stainless steel blocking electrodes. The impedance tests were carried out over the frequency range from $1 \mathrm{~Hz}$ to $100 \mathrm{kHz}$ at amplitude of $10 \mathrm{mV}$ using a potentiogalvanostatic PGSTAT 30 frequency response analyzer (Eco Chemie, The Netherlands). The film was sandwiched between two stainless steel disc electrodes $\left(3.142 \mathrm{~cm}^{2}\right)$. The measurements were conducted at room temperature and the ionic conductivities of the polymer electrolytes were calculated based on the following equation:

$$
\sigma=t / R_{\mathrm{b}} \mathrm{A}(1)
$$

The bulk resistance can be obtained from the impedance spectrum, and the thickness was measured after the impedance tests.

\section{FT-IR Analysis}

The FT-IR analyses were carried out at ambient temperature using Perkin-Elmer 2000 Spectrum spectrometer over the frequency range between 4000 and $400 \mathrm{~cm}^{-1}$.

\section{RESULTS AND DISCUSSION}

The (MG49- $\left.\mathrm{LiCF}_{3} \mathrm{SO}_{3}\right):\left[\mathrm{C}_{4} \mathrm{mPyrr}\right]\left[\mathrm{NTf}_{2}\right]$ films remained homogenous even after prolonged storage times ( $>6$ months) with no phase separation phenomenon, i.e. ionic liquid release was observed for the samples, thus suggesting a high physico-chemical stability of these SPE systems.

\section{FT-IR Measurements}

FT-IR spectroscopy analyzes the interaction between atoms or ions in the various solid polymer electrolyte systems. The FTIR of the pure materials and $\left(\mathrm{MG} 49-\mathrm{LiCF}_{3} \mathrm{SO}_{3}\right):\left[\mathrm{C}_{4} \mathrm{mPyrr}\right]\left[\mathrm{NTf}_{2}\right]$ polymer electrolyte are shown in Figures 1 and 2, respectively. For the MG49 polymer, characteristic vibrational bands of the $\mathrm{C}=\mathrm{O}$ stretching mode of PMMA appearing at $1737 \mathrm{~cm}^{-1}$ polyisoprene backbone. While the other vibrational bands at $2960 \mathrm{~cm}^{-1}, 2924 \mathrm{~cm}^{-1}$ and $1376 \mathrm{~cm}^{-1}$ are ascribed to $\mathrm{CH}_{3}$ asymmetric 
stretching, symmetric stretching and asymmetric deformation, respectively.

From the FT-IR spectra of the samples containing ionic liquid in the MG49- $\mathrm{LiCF}_{3} \mathrm{SO}_{3}$ system, it is observed that the $\mathrm{C}=\mathrm{O}$ vibration band becomes even sharper and shifted to lower wavenumber by about $5-15 \mathrm{~cm}^{-1}$. Since the structure of MG49 involves with $\mathrm{C}=\mathrm{C}$ backbone from polyisoprene unit and high density electron groups of $\mathrm{C}=\mathrm{O}$ and -COC- from PMMA backbone, the change of the $\mathrm{C}=\mathrm{O}$ band due to the presence of the salt, ionic liquid and/or the solvent can provide an important information concerning the interaction between $\mathrm{C}=\mathrm{O}$ and $\mathrm{Li}^{+}$coordination. Therefore, the occurrence of the polymer-salt-ionic liquid interaction is demonstrated [25]. The stretching frequency at $1267 \mathrm{~cm}^{-1}$ corresponds to C-O of COO- was observed in pure MG49 and disappeared on addition of the $\mathrm{Li}$ salt and ionic liquid were added. The characteristic vibrational frequency at $1448 \mathrm{~cm}^{-1}$ is assigned to $\mathrm{O}-\mathrm{CH}_{3}$ deformation of PMMA and as expected, the intensity increases with $\mathrm{LiCF}_{3} \mathrm{SO}_{3}$ content.
Passerini et al. have studied the interaction of the $\mathrm{Li}^{+}$cation with the $\left[\mathrm{NTf}_{2}\right]^{-}$anion in detail by Raman [26] and NMR [27] and showed that a strong interaction exists. In the present case the presence of sharpening and shifting of the $\mathrm{C}=\mathrm{O}$ bonds in MG49- $\mathrm{LiCF}_{3} \mathrm{SO}_{3}$ in the presence of the $\left[\mathrm{C}_{4} \mathrm{mPyrr}\right]\left[\mathrm{NTf}_{2}\right]$ ionic liquid indicates that at least some of the $\mathrm{Li}^{+}$interacts with the MG49 and this interaction competes favourably with the ionic liquid- $\mathrm{Li}^{+}$interaction, which agrees with our previous finding [28]. As the result, we can propose that this $\mathrm{Li}^{+} \ldots,\left[\mathrm{NTf}_{2}\right]^{-}$and $\mathrm{Li}^{+} \ldots$ $\left[\mathrm{CF}_{3} \mathrm{SO}_{3}\right]^{-}$interaction plays a role in the system of MG49- $\mathrm{LiCF}_{3} \mathrm{SO}_{3}-\left[\mathrm{C}_{4} \mathrm{mPyrr}\right]\left[\mathrm{NTf}_{2}\right]$ reducing the role of the $\mathrm{C}=\mathrm{O}$ chains in the coordination of the $\mathrm{Li}^{+}$cation.

\section{Electrochemical Impedance Spectroscopy}

The $\left(\mathrm{MG} 49-\mathrm{LiCF}_{3} \mathrm{SO}_{3}\right):\left[\mathrm{C}_{4} \mathrm{mPyrr}\right]\left[\mathrm{NTf}_{2}\right]$ based solid polymer electrolytes were evaluated for ohmic resistance. This was obtained from the intercept on the real impedance axis in the high frequency region. The ionic conductivities values at $25{ }^{\circ} \mathrm{C}$ for the (MG49$\left.\mathrm{LiCF}_{3} \mathrm{SO}_{3}\right):\left[\mathrm{C}_{4} \mathrm{mPyrr}\right]\left[\mathrm{NTf}_{2}\right]$ based solid polymer electrolytes are listed in Table 1.

Table 1. Composition and ionic conductivity of $\left(\mathrm{MG} 49-\mathrm{LiCF}_{3} \mathrm{SO}_{3}\right):\left[\mathrm{C}_{4} \mathrm{mPyrr}\right]\left[\mathrm{NTf} \mathrm{f}_{2}\right]$

\begin{tabular}{|c|c|c|}
\hline $\begin{array}{c}\text { Polymer Electrolyte Composition } \\
(\% \text { wt ratio) } \\
\left(\mathrm{MG49}-\mathrm{LiCF}_{3} \mathrm{SO}_{3}\right)\end{array}$ & $\begin{array}{c}{\left[\mathrm{C}_{4} \mathrm{mPyrr}^{\mathrm{mPT}}\left[\mathrm{NTf}_{2}\right]\right.} \\
\text { (\% wt ratio ) }\end{array}$ & $\sigma\left(\mathrm{S} \mathrm{cm}^{-1}\right)\left(\right.$ at $\left.25^{\circ} \mathrm{C}\right)$ \\
\hline 100 & 0 & $2.77 \times 10^{-6}$ \\
\hline $68: 22$ & 10 & $1.41 \times 10^{-4}$ \\
\hline $63: 27$ & 10 & $2.88 \times 10^{-4}$ \\
\hline $60: 20$ & 20 & $1.73 \times 10^{-3}$ \\
\hline $56: 24$ & 20 & $2.11 \times 10^{-3}$ \\
\hline
\end{tabular}

The data from Table 1 indicates that both the $\mathrm{LiCF}_{3} \mathrm{SO}_{3}$ and ionic liquid enhance the conductivity of the SPE samples and a synergistic effect is observed. The incorporation of $30 \%$ of $\mathrm{LiCF}_{3} \mathrm{SO}_{3}$ into pure MG49 with showed very low ionic conductivity at room temperature in the absence of the ionic liquid; however, on addition of the $\left[\mathrm{C}_{4} \mathrm{mPyrr}\right]\left[\mathrm{NTf}_{2}\right]$ the conductivity increased by two orders of magnitude. Importantly, the conductivity of MG49 incorporating both
$\mathrm{LiCF}_{3} \mathrm{SO}_{3}$ and ionic liquid is much higher than found for the MG49 incorporating an equivalent ion concentration of $\mathrm{LiCF}_{3} \mathrm{SO}_{3}$ alone.

The value of the $\sigma$ for $80 \%$ of $\left(\mathrm{MG} 49: \mathrm{LiCF}_{3} \mathrm{SO}_{3}\right)$ with $20 \%\left[\mathrm{C}_{4} \mathrm{mPyrr}\right]\left[\mathrm{NTf}_{2}\right]$ is higher by one order of magnitude in comparison to $90 \%$ of (MG49: $\mathrm{LiCF}_{3} \mathrm{SO}_{3}$ ) with $10 \%\left[\mathrm{C}_{4} \mathrm{mPyrr}\right]\left[\mathrm{NTf}_{2}\right]$. From our previous work, conductivities up to 1.84 x $10^{-4} \mathrm{~S} \mathrm{~cm}^{-1}$ were achieved in the same system 
with the presence of propylene carbonate (PC) at room temperature [29]. The increase of the conductivity with the increasing of $4-5 \%$ of $\mathrm{LiCF}_{3} \mathrm{SO}_{3}$ with $20 \%$ [ $\mathrm{C}_{4} \mathrm{mPyrr}$ ] $\left[\mathrm{NTf}_{2}\right]$ may be attributed to the increase in amount of the effective carrier ion. This is because, after dissociation of the $\mathrm{LiCF}_{3} \mathrm{SO}_{3}$ salt in the MG49 polymer, the charge carriers needed for conduction, may themselves act as transient crosslink. When a dopant salt is introduce into the polymer matrix, $\sigma$ increases rapidly owing to an increased number of charge carriers. The ion exchange between the $\left[\mathrm{CF}_{3} \mathrm{SO}_{3}\right]^{-}$and $\left[\mathrm{NTf}_{2}\right]^{-}$of the $\mathrm{Li}$ salt and ionic liquids is believed to play the role of conductivity enhancement. The presence of the $\left[\mathrm{NTf}_{2}\right]^{-}$anion reduces the Coulombic interactions with neighboring cations and induces increased ion mobility of the ionic liquid used. The decreased interaction is possibly due to extensive charge delocalization across the $\mathrm{SO}_{2}-\mathrm{N}$ $\mathrm{SO}_{2}$ moiety [30, 31] and much softer ionic bonding as found from the penetration of the cation into the anion shell within the liquid structure [our neutron work].

Figure 1. FT-IR spectra for pure materials

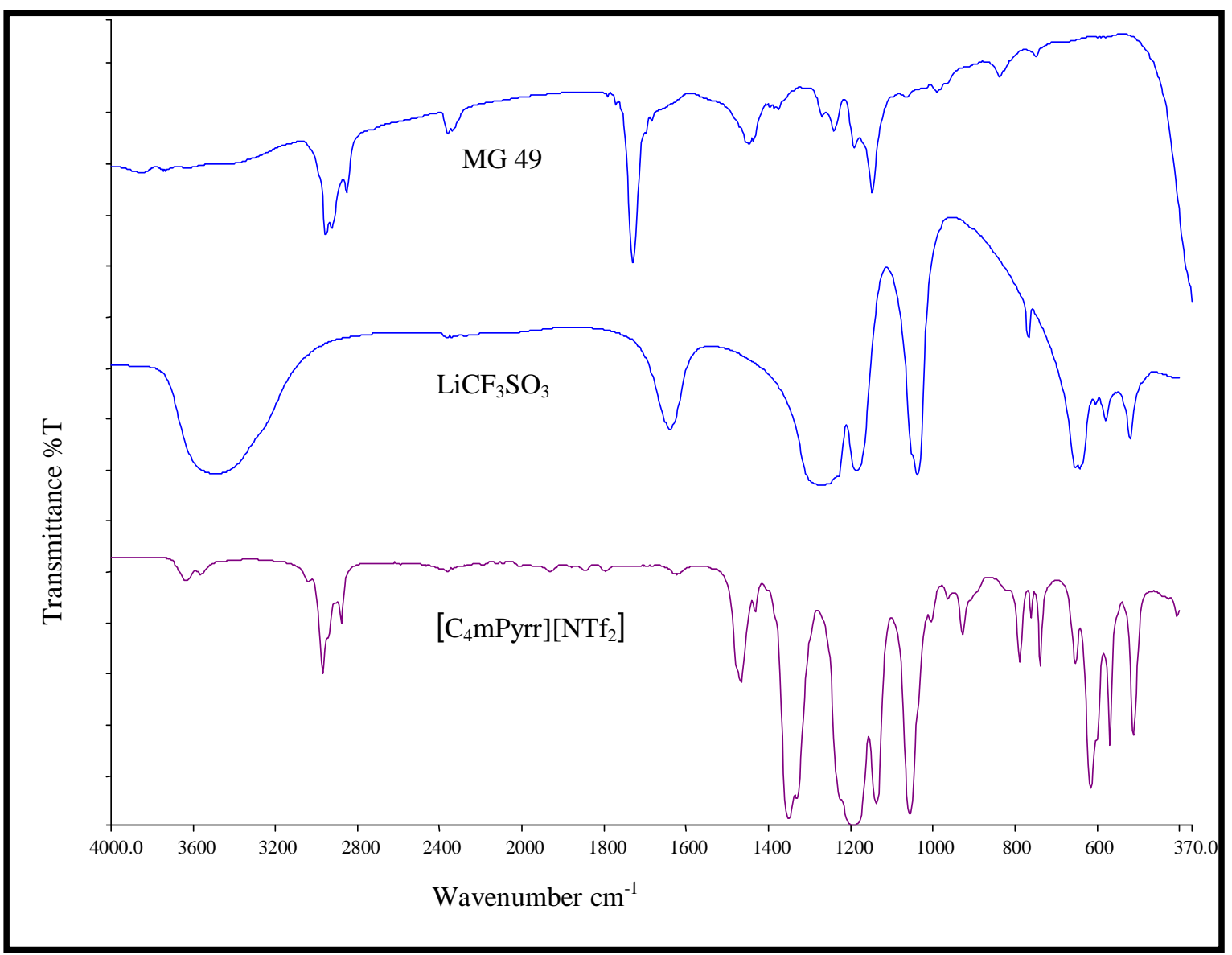


Malaysian Journal of Science 28 (2): 209- 215 (2009)

Figure 2. FT-IR spectrums for (a) MG49 (b) MG49 (70\%)- $\mathrm{LiCF}_{3} \mathrm{SO}_{3}(30 \%)$ (c) $\left[\mathrm{MG} 49-\mathrm{LiCF}_{3} \mathrm{SO}_{3}\right]^{\text {b }}$ $\left[\mathrm{C}_{4} \mathrm{mPyrr}\right]\left[\mathrm{NTf}_{2}\right](10 \%)(\mathrm{d})\left[\mathrm{MG} 49-\mathrm{LiCF}_{3} \mathrm{SO}_{3}\right]^{\mathrm{a}}-\left[\mathrm{C}_{4} \mathrm{mPyrr}\right]\left[\mathrm{NTf}_{2}\right](20 \%)(\mathrm{e})\left[\mathrm{MG} 49-\mathrm{LiCF}_{3} \mathrm{SO}_{3}\right]^{\mathrm{b}}-\left[\mathrm{C}_{4} \mathrm{mPyrr}\right]$ $\left[\mathrm{NTf}_{2}\right](20 \%)$

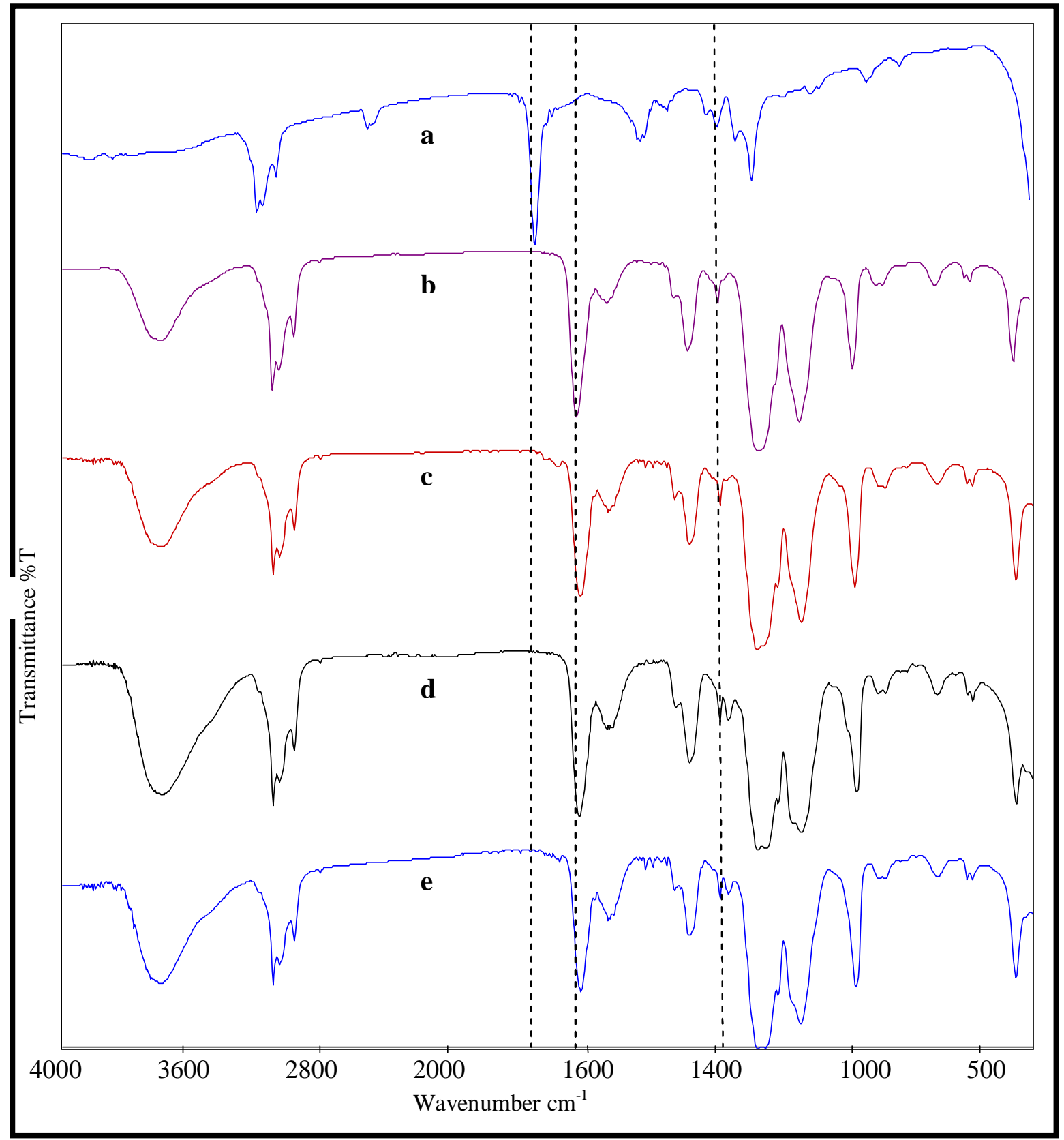




\section{REFERENCES}

1. MacFarlane, D.R., Sun. J., Forsyth, M., Meakin, P., Amini, N. (1999). Pyrrolidinium Imides: A New Family of Molten Salts and Conductive Plastic Crystal Phases. J. Phys. Chem.103: 4164-4170.

2. Shin, J.-H., Henderson, W.A., Passerini, S. (2003). Ionic liquids to the rescue? Overcoming the ionic conductivity limitations of polymer electrolytes. Electrochem. Commun. 5 (12): 1016-1020.

3. Chen, P.-Y. and Sun, I.-W. (2000). Electrochemistry of $\mathrm{Cd}(\mathrm{II})$ in the basic 1ethyl-3-methylimidazolium

chloride/tetrafluoroborate room temperature molten salt.

Electrochim. Acta, 45 (19): 3163-3170.

4. Katayama, Y., Dan, S., Miura, T., Kishi, T. (2001). Electrochemical Behavior of Silver in 1-Ethyl-3-methylimidazolium

Tetrafluoroborate Molten Salt. J. Electrochem. Soc. 148: C102.

5. Panozzo, S., Armand, M., Stephan, O. (2002). Light-emitting electrochemical cells using a molten delocalized salt. Appl. Phys. Lett. 80: 679.

6. Kubo, W., Kimura, T., Hanabusa, K., Wada, Yanagida, Y. S. (2002). Quasi-solid-state dye-sensitized solar cells using room temperature molten salts and a low molecular weight gelator. Chem. Commun.: 374-375.

7. McEwen, A.B., LeCompte, K., Goldman, J.L. (1999) Electrochemical properties of imidazolium salt electrolytes for electrochemical capacitor applications. J. Electrochem. Soc., 146:1687-1695.

8. Doyle, M., Choi, S.K., Proulx, G. (2000) High-temperature proton conducting membranes based on perfluorinated ionomer membrane-ionic liquid composites. $J$. Electrochem. Soc., 147: 34.

9. Nakagawa, H., Izuchi, S., Kuwana, K., Nukuda, T., Aihara, Y. (2003) Liquid and Polymer Gel Electrolytes for Lithium Batteries Composed of Room-Temperature Molten Salt Doped by Lithium Salt. $J$. Electrochem. Soc., 150: A695.

10. Sun, J., Forsyth, M., MacFarlane, D. R. (1998) Room Temperature Molten Salts Based on the Quaternary Ammonium Ion. J. Phys. Chem. B, 102: 8858.
11. Owens, G.S. and Abu-Omar, M.M. (2002) J. Mol. Cat A:Chem, 187: 215.

12. Kim, G.-T., Appetecchi, G.B., Alessandrini, F., Passerini, S. (2007) Solvent-free, PYR1ATFSI ionic liquid-based ternary polymer electrolyte systems: I. Electrochemical characterization. J. Power Sources, 171(2): 861-869.

13. Caja, J., Dunstan, T.D.J., Ryan, D.M., Katovic, V. (1999) The Electrochemical Society and The Electrochemical Society of Japan Meeting Abstracts 99-2: 2252.

14. Bazito, Fernanda F.C., Kawano, Y., Torresi, R.M. (2007) Synthesis and characterization of two ionic liquids with emphasis on their chemical stability towards metallic lithium. Electrochimica Acta, 52 (23): 6427-6437.

15. Bonhôte, P., Dias, A.P., Papageorgiou, N., Kalyanasundaram, K., Grätzel, M. (1996) Hydrophobic, highly conductive ambienttemperature molten salts. Inorg. Chem., 35:1168-1178.

16. Cooper E.I. and O'Sullivan E.J.M. (1992) In Proceedings of the Eight Internaional Symposium on Molten Salts (eds. R.J.Gale, G. Blomgren, and $\mathrm{H}$. Kojima) The Electrochemical Society Proceedings Series, Pennington, NJ PV 92-16, pp.386,

17. Wilkes,J.S. and Zaworotko, M.J. (1992) Air and water stable. 1-ethyl-3methylimidazolium based ionic liquids. Chem. Commun.: 965-967.

18. Papageorgiou, N., Athanassov, Y., Armand, M., Bonhôte, P., Petersson, H.,

Azam, A., Grätzel, M. (1996) J. Electrochim. Soc.143: 3009.

19. Tsunemi, K., Ohno, H., Tsuchida, K. (1983) A mechanism of ionic conduction of

poly (vinylidene fluoride)-lithium perchlorate hybrid films. Electrochimica Acta 28(6): 833837.

20. Alamgir, M. and Abraham, K.M. (1993) Li Ion Conductive Electrolytes Based on Poly(vinyl chloride). J. Electrochem. Soc. 140(6): L96-L97

21. Jun-Ling, Z., Xiao-gang, Z., Fang, X., FengPing, H. (2005) Effect of polar solvent acetonitrile on the electrochemical behavior of polyaniline in ionic liquid electrolytes. $J$. of Colloid and Interface Science 287: 67-71.

22. Pringle, J.M., Ngamna, O., Chen, J., Wallace, G.G., Forsyth, M., MacFarlane, D.R. (2006) Conducting polymer nanoparticles 
synthesized in an ionic liquid by chemical polymerization. Synthetic Metals 156(14-15): 979-983.

23. Fenton, D.E., Parker, J.M., Wright, P.V. (1973) Complexes of alkali metal ions with poly(ethylene oxide). Polymer 14: 589.

24. Gray, F.M., Armand, M. (2000) Energy Storage Systems for Electronics (eds. Osaka, T. and Datta M.), Gordon and Breach, Amsterdam.

25. Kim, C.S.and Oh, S.M. (2000) Importance of donor number in determining solvating ability of polymers and transport properties in geltype polymer electrolytes. Electrochim Acta 45(13): 2101-2109.

26. Castriota, M., Caruso, T., Agostino, R.G., Cazzanelli, E., Henderson, W.A., Passerini, S. (2005) Raman Investigation of the Ionic Liquid N-Methyl-N-propylpyrrolidinium Bis(trifluoromethanesulfonyl)imide and Its Mixture with $\mathrm{LiN}\left(\mathrm{SO}_{2} \mathrm{CF}_{3}\right)_{2}$. J. Phys. Chem. A 109(1): 92-96.

27. Nicotera, I., Olivieor, C., Henderson, W.A., Appetecchi, G.B., Paseerini, S.(2005) NMR Investigation of Ionic Liquid-LiX Mixtures: Pyrrolidinium Cations and TFSI Anions. $J$. Phy. Chem. B 109: 22814.
28. Kumutha, K. and Alias, Y. (2006) FTIR spectra of plasticized grafted natural rubber$\mathrm{LiCF}_{3} \mathrm{SO}_{3}$ electrolytes. Spectrochim Acta Part A: Molecular and Biomolecular Spectroscopy 64(2): 442-447.

29 Alias, Y., Ling, I., Kumutha, K. (2005) Structural and Electrochemical Characteristics of $49 \%$ PMMA Grafted Polyisoprene- $\mathrm{LiCF}_{3} \mathrm{SO}_{3}-\mathrm{PC}$ Based Polymer Electrolytes. Ionics 11: 414 -417.

30. Johansson, P., Gejji, S. P., Teggenfeldt, J., Lindgren, (1998) the imide ion: potential energy surface and geometries. $J$. Electrochim. Acta 43(10-11): 1375

31. Xue, L., Padgett, C.W., DesMarteau, D.D., Pennington, W.T. (2002) Synthesis And Structures Of Alkali Metal Salts of Bis[(Trifluoromethyl)Sulfonyl]Imide. Solid State Sci. 41535.

32. Golding, J., MacFarlane, D.R., Spiccia, L., Forsyth, M., Skelton, B.W., White, A.H. (1998) Weak intermolecular interactions in sulfonamide salts: structure of 1-ethyl-2methyl-3-benzyl imidazolium bis[(trifluoromethyl)sulfonyl]amide.

Chem. Commun. 15: 1593. 
Malaysian Journal of Science 28 (2): 209- 215 (2009) 